\title{
Melanosis coli: a case report
}

\author{
Anoop K V
}

\begin{abstract} to long-term laxative use. population with constipation.

\section{Background}

Melanosis coli is a brownish or blackish pigmentation of colonic mucosa caused by the deposition of lipofuscin in the intracellular cytoplasm. It has been attributed to long-term use of anthraquinone-based laxative use. It is an incidental and benign condition which is reversible within 6-12 months of stopping the laxatives [1]. The clinical significance lies in the fact that it can be confused with ischemic colitis [2].
\end{abstract}

Background: Melanosis coli is a benign condition characterized by deposition of lipofuscin in colonic mucosa due

Case presentation: Here I am reporting a case of an 85-year-old man who presented with constipation, with a history of long-term herbal medication intake as laxatives, and upon evaluation, he was found to have melanosis coli.

Conclusion: Melanosis coli is a common adverse effect of chronic laxative use which is more common in elderly

Keywords: Case report, Melanosis coli, Anthraquinone laxatives, Lipofuscin, Case report

\section{Case presentation}

An 85-year-old man was presented to me with a history of constipation since 2 years along with complaints of abdominal distension and early satiety. He was consuming a herbal medicine which he was taking over the counter for his constipation. He says he gets relief from constipation after consuming the herbal medicine. His physical examination was normal. His ultrasound abdomen did not show any significant abnormalities. His routine blood investigations were normal. He was taken up for a colonoscopy. His colonoscopy showed blackish pigmentation of colonic mucosa which was more in the right colon (Fig. 1). Multiple biopsies were taken throughout the colon. His histopathology report showed macrophages in the lamina propria with brown-black pigment in the cytoplasm. Histochemical staining

\footnotetext{
Correspondence: anoop85kv@yahoo.com
}

GEM Hospital, Thrissur, Kerala, India showed these pigments stained to Fontana-Masson and was suggestive of melanosis coli. The herbal medicine which he was consuming contained senna, which is an anthraquinone laxative and is notorious to cause melanosis coli. He was advised to stop the laxatives and was advised a healthy diet which includes vegetables, fruits, and legumes. He was also advised to do some exercises for healthy bowel movements. The patient improved with the above measures.

\section{Discussion}

Melanosis coli is a benign condition seen in patients using anthraquinone-based laxatives which is more common in the right colon. Anthraquinone laxatives affect colonocyte absorption, motility, and secretion and lead to cell loss and shortening of crypts. The damaged colonocytes are engulfed by macrophages and intracellular digestion results in the deposition of lipofuscin in the cytoplasm. Eldely population are at risk of developing melanosis coli especially those with chronic constipation [3].

Melanosis of the duodenum is a rare finding and has been attributed to a number of causes like chronic kidney disease, gastrointestinal bleeding, and folic acid deficiency. There is only a single case of melanosis in the jejunum reported which was thought to be caused by ferrous sulfate [4].

In our case, the patient was consuming a herbal medication which contained senna as an active ingredient.

\section{Springer Open}

(c) The Author(s). 2021 Open Access This article is licensed under a Creative Commons Attribution 4.0 International License, which permits use, sharing, adaptation, distribution and reproduction in any medium or format, as long as you give appropriate credit to the original author(s) and the source, provide a link to the Creative Commons licence, and indicate if changes were made. The images or other third party material in this article are included in the article's Creative Commons licence, unless indicated otherwise in a credit line to the material. If material is not included in the article's Creative Commons licence and your intended use is not permitted by statutory regulation or exceeds the permitted use, you will need to obtain permission directly from the copyright holder. To view a copy of this licence, visit http://creativecommons.org/licenses/by/4.0/. 


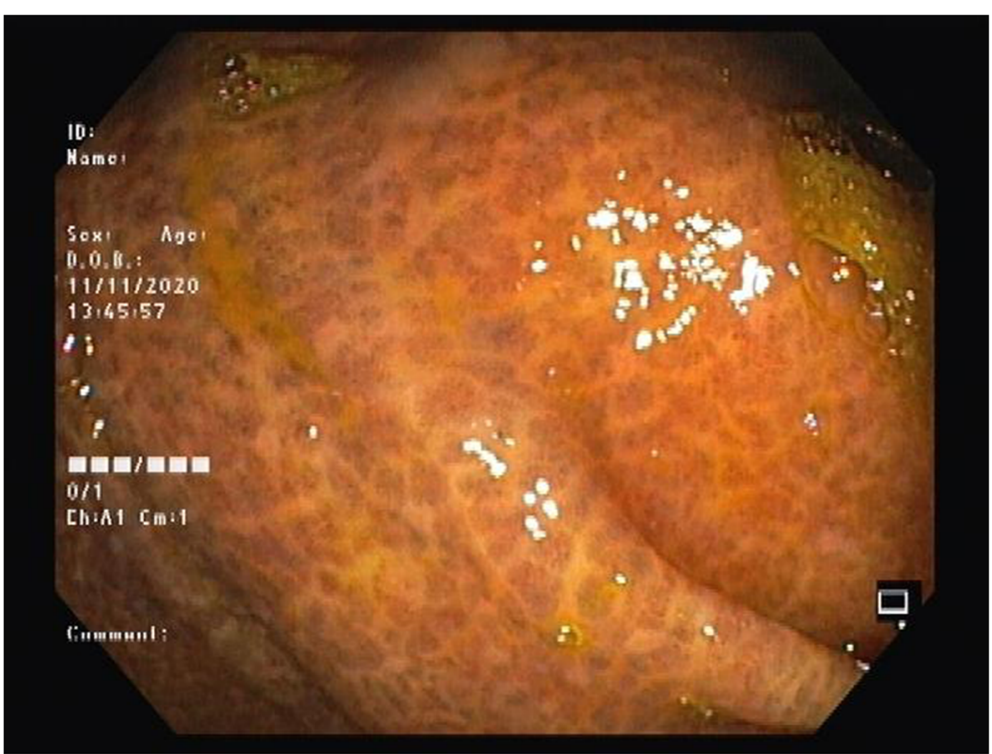

Fig. 1 Colonoscopy showing melanosis coli

Anthraquinone-based laxatives are aloe, cascara sagrada, frangula, senna, rhubarb, etc. He was advised to stop the medicine and a fiber-rich diet was advised. His constipation improved. Since the mucosa appears to be brown to black, it can easily be confused with ischemic colitis especially when it is extensive. Histologic findings of ischemic colitis that differentiate it from melanosis coli include distortion of crypts, edema, hemorrhagic changes of the mucosa and submucosa, inflammatory infiltration of the lamina propria, and necrosis [5]. There is an increased incidence of adenomas in patients with melanosis coli due to easier detection of adenomas against dark staining of colonic mucosa [6].

Even though there are lots of case reports on melanosis coli which has been reported from north India, there is no case report from this part of the country. Over-the-counter laxative intake and occurrence of melanosis coli is a frequent observation in colonoscopies, which are underreported. The significance lies in the misuse of laxatives without prescription, even though it is a benign condition.

\section{Conclusion}

Melanosis coli is a benign condition caused by chronic anthraquinone-based laxatives which is more common in elderly population with constipation. It is important to note that laxatives are not a solution for chronic constipation. A healthy bowel regimen that contains a diet rich in fruits, vegetables, and legumes as well as adequate hydration and exercise are equally important for healthy bowel movements. Foods like energy drinks, fried food, alcohol, red meat, and artificial sweeteners have to be avoided to prevent constipation.
Acknowledgements

Not applicable.

Author's contributions

The entire manuscript was prepared by the author himself. The author(s) read and approved the final manuscript.

Funding

None

Availability of data and materials

1. https://www.ncbi.nlm.nih.gov/pmc/articles/PMC4567734/

2. https://www.banglajol.info/index.php/JOM/article/view/5469

\section{Declarations}

Ethics approval and consent to participate

Consent to participate was obtained.

Ethical approval: Not applicable.

\section{Consent for publication}

Written informed consent to publish the information was obtained from the study participant.

\section{Competing interests}

The authors declare that they have no competing interests.

Received: 14 April 2021 Accepted: 1 June 2021

Published online: 15 July 2021

\section{References}

1. Modi RM, Hussan H (2016) Melanosis coli after long-term ingestion of cape aloe. ACG Case Rep 3(4):e157. https://doi.org/10.14309/cri.2016.130

2. Ricciuti B, Leone MC, Metro G (2015) Melanosis coli or ischaemic colitis? That is the question. BMJ Case Rep. https://doi.org/10.1136/bcr-2015-212404

3. Ahasan HM, Khan MAl, Mahbub S et al (2010) Melanosis coli-an atypical presentation. J Med 11(2):183-185. https://doi.org/10.3329/ jom.v11i2.5469

4. Ghadially FN, Walley VM (1994) Melanoses of the gastrointestinal tract. Histopathology 25(3):197-207. https://doi.org/10.1111/j.1365-2559.1994. tb01319.x 
5. Theodoropoulou A, Koutroubakis IE (2008) Ischemic colitis: clinical practice in diagnosis and treatment. World J Gastroenterol 14(48):7302-7308. https:// doi.org/10.3748/wjg.14.7302

6. Blackett JW et al (2018) Adenoma detection is increased in the setting of melanosis coli. J Clin Gastroenterol 52(4):313-318. https://doi.org/10.1097/ MCG.00000000000000756

\section{Publisher's Note}

Springer Nature remains neutral with regard to jurisdictional claims in published maps and institutional affiliations.

Submit your manuscript to a SpringerOpen ${ }^{\circ}$ journal and benefit from:

- Convenient online submission

- Rigorous peer review

- Open access: articles freely available online

- High visibility within the field

- Retaining the copyright to your article

Submit your next manuscript at $\boldsymbol{\nabla}$ springeropen.com 